\title{
Influence of personality, attitude, motivation, and environment on the entrepreneurial spirit of school cooperative teachers in vocational schools in Kulon Progo regency
}

\author{
Triatun Triatun *, Sukidjo Sukidjo \\ Universitas Negeri Yogyakarta. \\ Jl. Colombo No. 1, Karang Malang, Sleman, Daerah Istimewa Yogyakarta 55182, Indonesia. \\ * Corresponding Author. E-mail: chr.triatun@gmail.com
}

\section{ARTICLE INFO}

\section{Article History}

Received:

20 October 2017;

Revised:

1 July 2021;

Accepted:

1 July 2021;

Available Online:

8 August 2021

\section{Keywords}

Attitude;

Environment;

Entrepreneurial spirit;

Motivation;

Personality

\begin{abstract}
This study aims to determine the influence of personality, attitude, motivation, and environment on the entrepreneurial spirit both partially and simultaneously. The research method uses a survey with 39 teachers of school cooperatives and respondents numbering 33 people. Primary data was obtained using questionnaires supported by observations and interviews on cooperative teachers and related parties: data analysis using descriptive statistics and multiple regressions with t-test and $\mathrm{F}$ tests. The results showed that personality, attitude, motivation, and the environment simultaneously and partially influenced positively and significantly the entrepreneurial spirit. The four variables contributed to the entrepreneurial spirit by $80.30 \%$, while factors outside the research influenced $19.70 \%$. The environment is the variable that contributes the most to the entrepreneurial spirit with a percentage of $23.52 \%$, followed by personality by $20.91 \%$, motivation $19.88 \%$, and attitude $15.99 \%$.
\end{abstract}

This is an open access article under the CC-BY-SA license.



How to cite:

Triatun, T., \& Sukidjo, S. (2021). Influence of personality, attitude, motivation, and environment on the entrepreneurial spirit of school cooperative teachers in vocational schools in Kulon Progo regency. Harmoni Sosial: Jurnal Pendidikan IPS, 8(1), 45-56. https://doi.org/10.21831/hsjpi.v8i1.16439

\section{INTRODUCTION}

The entrepreneurial spirit is often associated with business activities or the field of entrepreneurship. But it can be applied to all areas because everyone has goals and will realize to achieve the goal. Therefore, the entrepreneurial spirit will be needed because it contains confidence if the person can accomplish that goal. Leadership is nothing but the ability of a person to coordinate various resources to create something of value, courage in taking risks, and thinking to be more advanced to benefit in the future by using creativity and innovation. As in Sukanti et al. (2011:80), the spirit of work, invention, discipline, innovation, persistence, work is not easily discouraged is a characteristic of superior soul required in any field.

The entrepreneurial spirit is confident, results-oriented, courageous risk-taking, leadership, future orientation, creativity, and innovation (Meredith et al., 2000). External and internal factors influence the entrepreneurial spirit. Internal factors are derived from entrepreneurs in personal traits, attitudes, wills, and abilities. External factors come from the environment, such as the family 
environment, business environment, physical, socioeconomic, education, and others (Suryana, 2008).

Personal or personality traits are specific traits that become the characteristic of a person for entrepreneurship as Goldberg (1971) stated in Hamilton et al. (2018) about personality traits, i.e., 1.) Openness to new experiences, imagination, and broad insights; 2.) Have an awareness of interests such as supervision, good awareness, and thoroughness; 3 .) It has extraversion such as friendliness, skill, and assertiveness; 4.) Have agreeableness or complete confidence, sincerity, compassion, and behavior leads to social action; and 5.) Neuroticism or emotional instability, always restless, moody, irritable. In Zhao and Seibert (2006) research, personality includes elements is 1.) Neuroticism(a person with stable emotional tendencies); 2.) Extraversion, someone who has more ability in analysis, active and creative; 3.) openness to experience, a person's tendency to be open and willing to seek helpful information; 4). Conscientiousness, people who want to work hard, loyal to institutions and work, have high motivation to achieve goals; and 5). Agreeableness, characteristic of a person who has a humble personality, cares deeply about others.

The teacher's personality as an educator can be demonstrated through loyalty to the school and the work it is responsible for. The teacher's personality is stated in Government Regulation of the Republic of Indonesia No. 19 of 2005 on National Standards, such as a steady, stable, mature, wise person, an example for students and their environment, willing to evaluate their performance and develop themselves (Presiden Republik Indonesia, 2005). The following internal factor is a person's attitude or assessment of the work they are responsible for. Based on the literature review, perspectives in entrepreneurship have been explained using The Theory of Planning Behavior (TPB) because its development about 20 years ago proved to be a solid approach for explaining human behavior (Sommer, 2011). Even Kautonen et al. (in Suharti \& Sirine, 2011) said that TPB could be widely used to disseminate entrepreneurship, politics, education (Kautonen et al., 2011: 1). This TPB element includes 1). Autonomy and authority; 2). Economic opportunity and challenge; 3.) Security and workload; 4.) Avoid responsibility; 5.) Self-realization and participation; 6.) Social environment and career; 7.) Perceived confidence.

The entrepreneurial spirit contains the element of making choices; therefore, Shane et al. (2003) explain that decision-making in entrepreneurship is strongly supported by motivation. The theory of motivation put forward by McClelland (in Alma, 2017) is divided into the need for achievement, power, and affiliation. Amit et al. (2019) said that the motivational dimension is divided into motivations towards achievements divided into 1.) Achievements, challenges, and learning; 2.) Independence and autonomy; 3.) Financial security; 4.) Recognition and status; 5.) Family and role; 6.) Dissatisfaction; 7.) Encouragement to be recognized by society.

The entrepreneurial spirit can be influenced by external factors or the environment around which a person is located. The environment is a microsystem environment (the microsystem)that is the closest environment of a person is, including family, colleagues, and neighbors. The most extensive background is the macrosystem environment (macrosystem), which is the most widespread level that includes the socio-cultural structure in general (Puspitawati, 2009). According to Gnyawali and Fogel (1994), the environment that affects the entrepreneurial spirit includes government policy, socioeconomic circumstances such as (successful entrepreneur figures, comparison of small and large businesses, the number of entrepreneurs who are easy to model), supporting funds, entrepreneurial ability, non-financial factors such as communication facilities, availability of domestic and foreign information, government attention in the development of the business climate, business networks, the emergence of supporting business consultant or management services. Considering the entrepreneurial spirit is indispensable in all fields of work. Therefore, it is appropriate if the actors or people involved in education have an entrepreneurial spirit to equip students to plunge into society as the next generation is expected to be more qualified than the current generation.

In the sphere of formal education, students are taught entrepreneurship to equip knowledge, skills. According to the Regulation of the Minister of National Education of the Republic of Indonesia No. 39 of 2008 concerning Student Development, school cooperatives mentioned creativity, skills, and entrepreneurship are realized in the efforts of school cooperatives and production units (Menteri Pendidikan Nasional Republik Indonesia, 2008). School cooperatives are 
led by cooperative school teachers responsible for the operational management of school cooperatives. The main task is to foster students' entrepreneurial spirit or students who become administrators of school cooperatives.

In Badeni (2000), the teacher of the cooperative school coach is the teacher who the principal gives the task to coach the school cooperative in the sense of guiding and supervising the operational activities of the school cooperative. In secondary school, the teacher of the cooperative coach is a teacher in economic studies or another teacher who was chosen because he has knowledge or experience in cooperatives as a student council teacher to accompany the development of entrepreneurship or cooperation among the students.

Therefore, to produce entrepreneurial graduates should be guided by entrepreneurial teachers. In this case, teachers have insight or entrepreneurial experience to produce entrepreneurial graduates. School cooperatives are very suitable to be applied at the secondary education or vocational school level, considering the purpose of such education is to prepare graduates to win in the job market or create jobs in a particular field. However, not all school cooperatives can be run as intended. In the study, Nurbudiyani (2013) stated that the activities of school cooperatives in vocational schools have not fully demonstrated as they function. The condition can be said that the entrepreneurial spirit among students has not been well built because it has not been given a briefing to fulfill cooperation and entrepreneurship by teachers of school cooperatives. While the research conducted by Sari (2013), the existence of school cooperatives has many problems in terms of the diverse personalities of the principal and the school cooperative's accompanying teachers. The headmaster is less accustomed to being independent in making decisions, less maximal in managing school resources, and problems in teachers, namely the mentality of less independent teachers, accustomed to uniform patterns, and lack creativity.

Cooperatives have been introduced since we entered primary education through school cooperatives. Once adults, people engage with cooperatives, especially credit cooperatives, as an alternative that facilitates and relieves people to obtain funds quickly. But objectively, none of the cooperatives in Indonesia was included in the list of the world's 300 best cooperatives in release in 2012 by the ICA(International Cooperative Alliance)as the parent cooperative of the world (Dalimunte, 2015).

The process of cooperative learning in schools through school cooperatives can be a manifestation of the expectations desired by the government that cooperatives are teachers of the people's economy. Through the same school, cooperatives mean that it has been cultivated cooperative life to the younger generation who will replace the cooperative actors who are active today. In the cooperative movement, it takes togetherness to achieve the goal. Each member is expected to have the awareness to live together to help themselves and others. But to form such a character is not easy or can be formed briefly even the rapid development of technology and information is controlled to eliminate the culture of cooperation so that cooperatives are less in demand by the next generation. Thus the planting of cooperative living culture should be introduced through formal education.

Currently, in the Special Region of Yogyakarta has appeared public figures namely The Regent of Kulon Progo Dr. Hasto Wardoyo, S.P.OG, who has worked a lot for the progress and independence of Kulon Progo Regency, which has long been the poorest district in DIY. From the creative thought has given rise to various programs including the people, one of which is bela-beli Kulon Progo, was initiated and pledged as an ideological spirit towards independence in the economic field to seize the market in the Kulon Progo region by exploring the creativity of Kulon Progo community to create innovative products such as batik geblek renteng which the Kulon Progo community must wear, especially students and employees both private and public. In the field of agriculture produced superior rice menor and other products that the people of Kulon Progo must consume. In addition, he has worked a lot for the empowerment of cooperatives in Kulon Progo Regency, as in the following in the Table 1.

In Table 1, it is seen that the number of cooperatives from year to year is increasing. Related to the program bela-beli Kulon Progo, has been issued in Regional Regulation of Kulon Progo, Republic of Indonesia Number 11 In 2011 on The Protection and Empowerment of Traditional Markets as well as the Arrangement of Shopping Centers and Modern Stores that have the status of 
networks and franchises so that an agreement is reached for cooperation in the economic empowerment of the community that is a partnership between cooperatives and MSMEs through tomira or people's stores (Bupati Kulon Progo, 2011).

Table 1. Cooperative Development in Kulon Progo

\begin{tabular}{llcccccccc}
\hline No. & Information & $\begin{array}{c}2009 \\
\text { unit) }\end{array}$ & $\begin{array}{c}2010 \\
\text { (unit) }\end{array}$ & $\begin{array}{c}2011 \\
\text { (unit) }\end{array}$ & $\begin{array}{c}2012 \\
\text { (unit) }\end{array}$ & $\begin{array}{c}2013 \\
\text { (unit) }\end{array}$ & $\begin{array}{c}2014 \\
\text { (unit) }\end{array}$ & $\begin{array}{c}2015 \\
\text { (unit) }\end{array}$ & $\begin{array}{c}2016 \\
\text { (unit) }\end{array}$ \\
\hline 1. & KUD & 12 & 12 & 12 & 12 & 12 & 12 & 12 & 12 \\
2. & NON KUD & 298 & 305 & 324 & 333 & 341 & 353 & 365 & 380 \\
& sum & 310 & 317 & 336 & 345 & 353 & 365 & 377 & 292 \\
\hline
\end{tabular}

Source: (ToMiRa, Model Pemberdayaan UMKM Dari Kulon Progo, 2017)

According to Wardoyo (in Pemerintah Kabupaten Kulon Progo, 2012), cooperatives should start from the real sector to create a business climate for industry and MSMEs. School cooperatives in vocational schools are expected to move into the real sector so that it is expected to develop seeds that can move cooperatives on a wide scale. Like the school cooperative in SMK Negeri 1 Nanggulan has successfully run a business of cattle farms, ducks, chickens, poultry, catfish. Vocational School. The cooperatives bridge products in each major with a market (Pemerintah Kabupaten Kulon Progo, 2012).

Given the importance of school cooperatives for the continuation of cooperatives in general, the existence of school cooperatives in carrying out their business is inseparable from the role of teachers of school cooperatives. This is interesting to be researched teachers' ability to coach school cooperatives in managing school cooperatives in vocational schools in Kulon Progo Regency. Until now, no research has been found that reveals the entrepreneurial spirit of cooperative school teachers in the same region.

At a certain time, this research is expected to have broad benefits for the welfare of the Kulon Progo community. In addition to the success that has been achieved in cooperatives, Kulon Progo Regency currently has an excellent opportunity to develop. It is marked by laying the first stone in the Temon Kulon Progo Subdistrict anchor area to sign that the International Airport is ready to open. Other mega-project plans such as toll road, railway construction, and the potential of natural tourism Kulon Progo continue to be empowered. Therefore, the Kulon Progo area becomes the target of investors to participate in taking a profit. This opportunity must be captured by the people of Kulon Progo, not to be captured by other parties outside the Kulon Progo area. Students as a young generation must be instilled entrepreneurial spirit to defend, maintain, empower Kulon Progo District. One way can be through school cooperatives.

Pre-observation activities and interviews with related parties such as teachers of school cooperatives, public and private schools, the Education Office, the local Cooperative Office have been conducted before the research. The observations and interviews in 28 vocational schools do not all have school cooperatives that schools specifically use as a medium of entrepreneurial learning. However, some school cooperatives do not actively involve students but are only done by teachers and employees because it is considered an obstacle to academic activities. Through interviews can be described various problems related to school cooperatives: 1.) Not all vocational schools have school cooperatives. New schools are standing so that the limitations of teachers who can manage school cooperatives and schools whose number of students are far below standard so that it is less efficient if held by school cooperatives; 2.) The principal and accompanying teachers of the school cooperative have not fully understood the importance of school cooperatives for students and their benefits for the school. They pay less attention to the importance of cooperative learning because the school prioritizes achievement in the academic field; 3.) Limited experience of school cooperative teachers in entrepreneurship so that creativity in developing cooperatives has not been maximized even the operational activities of school cooperatives are hampered; 4.) The teacher chosen by the principal to be given the position as the cooperative school coach is not entirely based on the ability to manage the school cooperative but because of other things such as teachers who lack teaching 
hours so as not to teach elsewhere; 5.) Teachers of school cooperatives cannot yet thoroughly read opportunities or opportunities that can be used as entrepreneurial learning materials for students; 6. ) Factors motivate teachers to coach school cooperatives in managing them because they have not fully pursued achievements but in personal interests to gain material benefits; 7.) The assessment of teachers and principals on the existence of school cooperatives still considers the advantages of school cooperatives to be based on material rather than non-material looking material such as instilling the nature of togetherness, honesty, caring, discipline and responsibility; and 8.) The cooperative office and education office have not shown concern for school cooperatives in vocational schools. Based on the description of various problems, continued research with the title "influence of personality, attitude, motivation, and environment on the entrepreneurial spirit of teachers coaching school cooperatives in vocational schools in Kulon Progo District." This research has focused on entrepreneurial spirit, personality, attitude, motivation, and environment.

\section{METHOD}

This research is a descriptive study that intends to describe each variable and know the influence of causality of one free variable, in this case, personality, attitude, motivation, and environment, to the bound variable (entrepreneurial spirit) that has not been known before. At the same time, the approach uses quantitative to see the contribution of each free variable to bound variables. The research has been conducted on teachers of school cooperatives in 16 (sixteen) vocational schools, both public and private, in the Kulon Progo Regency. The population in this study is all teachers of school cooperatives in vocational schools in Kulon Progo district, both in public and private vocational schools that organize school cooperatives for entrepreneurial learning activities. Therefore, the number of vocational schools with cooperative schools that are eligible for research places amounts to 22 schools. However, because the teacher in question was given the task for education training over function at the research process, 16 schools were obtained that could be used as research places with 33 teachers who are still active school cooperatives. Considering the population is below 100 people, this study does not use samples. Still, all school cooperatives in vocational schools in Kulon Progo district have been made respondents or called population research.

To obtain data on the entrepreneurial spirit, motivational attitudes, and the environment is carried out with various steps, namely, the research begins with the identification of problems, limitation of problems that will be the focus of research, literature studies continued the process of making instruments in the form of questionnaires that are closed by using the Likert scale on four scales. Before the research is done first, the instrument is validated by asking for the help of validators in the field of cooperation and entrepreneurship to check the feasibility of research instruments based on theory and previous research.

The next step is to retrieve the data for the whole variable by asking 33 respondents to fill out a questionnaire. The data obtained has been tested the validity level with CFA (Confirmatory Factor Analysis) through the help of SPSS 16. Criteria valid or not a question item if the value of KMO (Keyzer Meyer Olkin), whose value must be greater than 0.5, and MSA value (Measures of Sampling Adequacy) and communalities value above 0.5.

At the same time, the Alpha Cronbach Method is used to calculate the reliability of a test that measures attitude. The data obtained immediately conducted multiple regression prerequisite tests that included normality, linearity, multicollinearity, and heteroskedasticity, then continued with multiple regression analyses. With the following equation of regression is. The information: b1, b2, b3, b4: coefficient of regression line; Y: entrepreneurial spirit; X1: personality; X2: attitude; X3: motivation; X4: environment. To test the hypothesis, free variables' influence on individually bound variables was used Partial Statistical Test $(\mathrm{t})$. While test $\mathrm{F}$ is used to test hypotheses, free variables are influenced by simultaneously bound variables. The basis of decision-making is to compare the significance value of the calculation result with a confidence level of 5\% (Hadi, 2001). 


\section{RESULT AND DISCUSSION}

Based on descriptive analysis obtained an overview of the entrepreneurial spirit and attitude of teachers coaching school cooperatives, the majority falls into very high; personality and environment majority fall into the high category, and motivation largely falls into the moderate category. Through the help of SPSS 16 multiple regression analysis, the results are obtained as can be seen in Table 2. Tables 3 and 4 present the results of the partial regression analysis and the results of the simultaneous regression analysis. Based on the results of data analysis will be described in the analysis paradigm which can be seen in Figure 1.

Table 2. Multiple Regression Analysis Results

\begin{tabular}{clrrrrrrr}
\hline Bound Variable & Free Variables & $\mathrm{b}$ & $\mathrm{Sr}$ & $\mathrm{R}$ Square & $\begin{array}{l}\text { Adjusted } \\
\text { R Square }\end{array}$ & Sign & Cst \\
& personality & 0,392 & 0,216 & & & 0,014 & & \\
Entrepreneurial & attitude & 0,366 &, 164 & 0,828 & 0,803 & 0,023 & 0,002 & 17,000 \\
mpirit & motivation & 0,356 &, 205 & & & 0,011 & 0,002 \\
& milieu & 0,327 &, 243 & & & 0,017 & & \\
\hline
\end{tabular}

Tabel 3. Partial Regression Analysis Results

\begin{tabular}{cccccc}
\hline type & $\begin{array}{c}\text { Unstandardized Coefficient } \\
\text { beta }\end{array}$ & $\begin{array}{c}\text { Standard } \\
\text { error }\end{array}$ & $\mathrm{t}$ table & $\mathrm{t}$ count & Sign \\
\hline Constant & 17 & 5,054 & & 3,364 & 0,002 \\
personality & 0,392 & 0,15 & 2,048 & 2,608 & 0,014 \\
attitude & 0,355 & 0,153 & 2,048 & 2,397 & 0,023 \\
motivation & 0,353 & 0,13 & 2,048 & 2,738 & 0,011 \\
milieu & 0,327 & 0,129 & 2,048 & 3,537 & 0,017 \\
\hline
\end{tabular}

Table 4. Results of Simultaneous Regression Analysis

\begin{tabular}{ccccccc}
\hline type & Sum of Square & Df & Mean & F count & F Table & Sign \\
Regression & 1200,314 & 4 & 300.079 & 33,667 & 2,71 & 0,00 \\
Residual & 249,564 & 28 & 8,913 & & & \\
Total & 1449,879 & 32 & & & & \\
\hline
\end{tabular}



Figure 1. Paradigm Analysis

The table shows that the results of multiple regression analysis in the table unstandardized coefficient beta positive value with a sign of 0.00 show each free variable that is personality, attitude, 
motivation, and environment, affecting the entrepreneurial spirit positively and significantly. In the first partial analysis, personality influenced the entrepreneurial spirit of cooperative school teachers at vocational schools in Kulon Progo District positively and significantly seen in the Beta value of 0.392 and the coefficient of personality variables. A positive coefficient can describe a productive school cooperative teacher's personality to make a useful contribution to the development of school cooperatives. Teachers, in this case, are equivalent to managers in companies that coordinate all resources in school cooperatives.

School cooperatives can be useful following their functions in need of the personality of a teacher who is assertive, skilled, has the emotional stability, sincere, compassionate, open to experience, willing to develop themselves, very sensitive to the needs of students, or able to read business opportunities that school cooperatives can do. Such a teacher's personality can positively influence the entrepreneurial spirit of the teacher of the school cooperative in terms of confidence to start a business with a result-oriented without forgetting the process so that if there is a risk of being able to be responsible as valuable learning. The willingness of teachers to explore a variety of knowledge and experience makes teachers more creative in planning various work programs or activity plans for the long term or future that benefit students.

According to Crant (1996) supported this research that productive personality is the most influential factor to the entrepreneurial spirit. Other researchers such as Gadar and Kamal (2009) proved that personality factors are the most potent variable in influencing the entrepreneurial spirit. Schmitt-Rodermund (2004) stated that the positive and significant personality of the entrepreneurial spirit is greater than the interest in becoming an entrepreneur. The contribution of relative personality variables to entrepreneurial spirit variables by $20.91 \%$ or relative contributions to 0.2091 .

In the second partial analysis, that attitude influenced the entrepreneurial spirit of cooperative school teachers in vocational schools in Kulon Progo District positively and significantly seen in the Beta value of 0.366 at the significance of $0.023<0.05$. In addition, the relative contribution of variable attitudes towards entrepreneurial spirit variables amounted to $15.99 \%$ or 0.1599. Supported by Gird and Bagraim (2008) research, TPB contributes $27 \%$ in building entrepreneurial spirit. The next researcher is Engle et al. (2010), with TPB model results successfully positively and significantly influence students' entrepreneurial spirit in each country.

The attitude in this study is the assessment of the teacher of the cooperative school coach to his duties and responsibilities as the leader of the school cooperative or manager. He referred to the research of Warmanto and Thenu (2009), who have applied the TPB model to managers from every level who are still actively working in a company or organization in the Jakarta area. Attitude indicators include autonomy/authority, economic challenge, self-realization, perceived confidence, security \& workload, avoid responsibility, and social career. In the data analysis, the positive number in the Beta column (0.366) explains that attitudes positively affect the entrepreneurial spirit. The teacher of the cooperative school coach positively assesses the task given by the principal as the person in charge of the school cooperative.

School cooperative coaches are allowed to express all their abilities freely and independently, the opportunity to increase the lack of teaching hours, earn additional income, achieve achievements and opportunities to improve careers. Positive assessment of the indicators in theory of planned behavior can positively influence the entrepreneurial spirit of cooperative school teachers in vocational schools in Kulon Progo Regency. Teachers of school cooperatives have obtained many profitable opportunities, such as financially and non-financially gaining profits to trigger hard work through creativity and innovation to achieve the planned results. In the third partial analysis, the motivation influenced the entrepreneurial spirit of cooperative school teachers at vocational schools in Kulon Progo District positively and significantly seen in the Beta value of 0.356 with a significance of $0.011<0.05$. While the magnitude of the influence of motivation variables on the entrepreneurial spirit by $19.88 \%$ or 0.1988 .

These results prove the research conducted by Collins et al. (2004) with the results of motivation to significantly positively affect the entrepreneurial spirit in preparing for a career as an entrepreneur. Furthermore, Segal et al. (2005) have conducted research showing a positive and significant motivational influence on the entrepreneurial spirit. Motivation, in this case, is the encouragement of teachers of school cooperatives to achieve the success of school cooperatives as a 
medium of entrepreneurial learning. Teachers who want success are more concerned with achievement than material rewards.

The values obtained in the analysis can be interpreted as the higher the motivation of the teacher of the cooperative school coach to achieve the achievement, the higher the entrepreneurial spirit of the cooperative teacher coach. Highly motivated school cooperative teachers will have a high level of personal responsibility for their work, have a work program based on realistic plans and objectives and strive to realize it, can make decisions and dare to take risks faced, do a real job to achieve satisfactory results, have the desire to be the one who mastered a particular field. Such characteristics give rise to the entrepreneurial spirit to manage school cooperatives to learn to be entrepreneurial. They are shaping the character of students into honest individuals, independent, able to work together. Supported by observations and interviews of all respondents, teachers who are highly motivated school cooperatives try to be loyal to the school and its environment to create a good name for the school through school cooperatives. They design and realize activities that foster student creativity, such as culinary product exhibition activities that raise local products. Dare to take risks, such as giving business capital to students with certain conditions and requirements, so children are trained to set up a business. They are designing the reach of school cooperative services for the general public.

In the fourth partial analysis, the environment influenced the entrepreneurial spirit of cooperative school teachers at vocational schools in Kulon Progo District positively and significantly seen in the beta value or coefficient of environmental variables of 0.327 at a significance of $0.017<0.05$. The meaning of 0.327 , which is positive, explains that the more insights and experiences gained from the environment, family, work (school), and social environment, the better the entrepreneurial spirit is to develop school cooperatives. These results are supported by research conducted by Klyver et al. (2008) that the entrepreneurial spirit is positively and significantly influenced by one's experience while becoming a business person. Such influence can be meaningful because the level of trust is above $95 \%$ or the tolerance of wrongdoing is below 5\%.

The entrepreneurial spirit of school cooperative teachers to develop school cooperatives can be influenced by the environment in which they are located. Starting from the family environment, the work environment, in this case, is the school environment and the social or community environment (the wider environment). Observations and interviews of all respondents have supported the results of the statistical analysis for approximately one month. The family environment can affect the entrepreneurial spirit of cooperative teachers such as the habits of light things such as discipline in managing time, habits in frugality, family environment that fosters helpful attitudes, tolerance, strength in the family in instilling the basics of religious education, cultural background and livelihood, insufficient material needs and relationships between family members.

In addition, experience in a family environment with economic limitations or needs that are not sufficient because since childhood has been taught by his parents or other families to be involved in making a living in both the field of trade and agriculture that is able to provide provisions to the concerned on how to solve problems, take opportunities and practice risk management of decisions taken. Everything that has been experienced since childhood will make it easier for teachers to manage school cooperatives to know what to do related to various problems and opportunities. In this study, most of the teachers of school cooperatives had independent businesses. This is supported by research conducted by Chlosta et al. (2010) that parent or family role models affect their children's entrepreneurial spirit, for example, in deciding a career. Parents who work independently as selfemployed will affect the child to choose to work independently.

According to Salimath and Cullen (2010) states that informal and non-formal institutions affect the entrepreneurial spirit. According to Aldrich and Zimmer (1986), the environment is a resource that can be utilized for various beneficial activities through one's creativity. In this environment, there is a social network in communication or delivery of information from person to person to exchange goods and services. Profitable environmental opportunities such as strategic school location and the ability of the school to cooperate with external parties is an opportunity for school cooperatives to expand the marketing reach of each major's products. The atmosphere of the work environment or comfort in establishing relationships with fellow teachers and the principal's policy on the existence of school cooperatives will affect the leadership of the cooperative school 
teacher. The ability of teachers to adjust to changes in the social environment, such as being able to adjust to the development of technology, seeking information and a wide social network, the willingness of teachers to hone skills in certain fields, influences the creativity of teachers in planning work programs to their implementation techniques.

Supported by interviews with all teachers of cooperative coaches obtained information that $70 \%$ of the total respondents have experience about self-management, have social networks such as being active in the activities of religious organizations or village organizations in the field of entrepreneurship, active in social organizations related to the processing of creative products. Based on observations before the study found one-fifth of $20 \%$ of the total school cooperatives in Kulon Progo can be said that the cooperative has carried out its activities following its objectives such as cooperatives have actively engaged students to take part in the process of developing school cooperatives, there is a diversification of business in this case businesses outside the provision of student needs in the school but has involved outside parties as consumers. The cooperative the widespread business premises can see every development period, the volume of products sold, the number of students involved.

In the fifth analysis that the variables of personality, attitude, motivation and environment simultaneously positively and significantly affect the entrepreneurial spirit of school cooperatives. The entire Beta value represents a positive value with $R$ Square 803 and in table 3 of the Fcalculate $>\mathrm{F}$ table $(33,667>2.71)$. This means that the entrepreneurial spirit of cooperative school teachers is influenced by personality, attitude, motivation, and environment by $80.3 \%$, and other factors outside of this study influence $19.7 \%$. Environmental variables greatly affect the variables of the entrepreneurial spirit. School cooperative teachers' ability to adjust to the environment in which they are located is the most influencing factor in the entrepreneurial spirit in determining the orientation of results, leadership, creativity, courage to take risks, confidence, and future-oriented.

\section{CONCLUSION}

Based on the statistical data processing, it can be concluded that each free variable (personality, attitude, motivation, and environment) can partially have a positive and significant influence. Personality (sign.0,014<0.05); attitude (sign. $0.023<0.05$ ); motivation (sign. $0.023<$ 0.05 ); (sign. $0.011<0.05$ ). While personality, attitude, motivation, and environment positively and significantly affect the entrepreneurial spirit with effective contributions of $80.3 \%$ and relative contributions of $20.91 \%$ each personality; attitude of $15.99 \% ; 19.88 \%$ and the environment $23.52 \%$. Thus the entrepreneurial spirit of school cooperative teachers in vocational schools in Kulon Progo district is strongly influenced by the ability to adjust to the environment, be it family, school, and social environment.

Based on the discussion results and conclusions, several parties are expected to make inputs related to the management of school cooperatives, among others for the Office of Cooperatives. SMEs and the Education Office of Kulon Progo District collaborated to organize a special official forum for teachers of school cooperatives to socialize the importance of school cooperatives, technical coaching related to the management and operational activities of school cooperatives as a step to the next generation that drives cooperatives in general, especially in Kulon Progo Regency. In addition, there is also an activity as a place to pour creativity vocational school students, for example, an exhibition of innovative products derived from the work of vocational school students in Kulon Progo district. Head of vocational school in Kulon Progo district provides facilities and infrastructure for school cooperatives as a medium of student entrepreneurship learning. For example, the location of school cooperatives should be strategically affordable by outside schools to open business diversification opportunities. Teachers of cooperative coaches as the driving force for achieving the objectives of school cooperatives should the principal choose teachers to be assigned as student coaches in cooperation so that it is based on the ability of the teacher concerned related to the tasks that must be completed in the school cooperative. Teachers do not have to have a suitable educational background, such as teachers from economic education but do not close the possibilities for others. 
To generate motivation for school cooperative teachers, the principal should be creative and innovative to reward the hard work of school cooperative teachers, both material and non-material. The principal should be able to establish communication with the school cooperative teacher to cooperate in planning the school cooperative development program. Principals and teachers of school cooperatives seek to expand their knowledge by expanding social networks, both private and formal organizations in external and internal environments, to facilitate reading business opportunities for school cooperatives. For example, teachers are active in organizations related to environmental management. So that teachers can apply in school cooperatives in terms of waste management into valuable products. The principal should cultivate discipline, honesty, independence for all school residents as capital in achieving success. The principal must have a positive mindset on the functions and benefits of school cooperatives. Students who are active in activities in school cooperatives are not an obstacle to academic success but an effort to build soft skills as student capital in addressing their life problems. Academic achievement has not guaranteed one's success.

\section{REFERENCES}

Aldrich, H., \& Zimmer, C. (1986). Entrepreneurship through social networks. In California Management Review (Vol. 33, pp. 3-23).

Alma, B. (2017). Kewirausahaan untuk mahasiswa dan umum (22nd ed.). Alfabeta.

Amit, E., Rim, S. Y., Halbeisen, G., Cohen Priva, U., Stephan, E., \& Trope, Y. (2019). Distancedependent memory for pictures and words. Journal of Memory and Language, 105(December 2018), 119-130. https://doi.org/10.1016/j.jml.2019.01.001

Badeni, B. (2000). Pendidikan ekonomi dalam membelajarkan dan membina perilaku siswa dalam berkoperasi: Studi kualitatif mengenai partisipasi siswa dalam berkoperasi di SLTA Kodya Bandung [Universitas Pendidikan Indonesia]. http://repository.upi.edu/id/eprint/56578

Bupati Kulon Progo. (2011). Peraturan Daerah Kabupaten Kulon Progo Nomor 11 Tahun 2011 tentang Perlindungan dan Pemberdayaan Pasar Tradisional serta Pusat Perbelanjaan dan Toko Modern.

Chlosta, S., Patzelt, H., Rau, S., \& Dormann, C. (2010). Parental role models and the decision to become self-employed: The moderating effect of personality. Small Business Economics, 38, 121-138. https://doi.org/10.1007/s11187-010-9270-y

Collins, C. J., Hanges, P. J., \& Locke, E. A. (2004). The relationship of achievement motivation to entrepreneurial behavior: A meta-analysis. Human Performance, 17(1), 95-117. https://doi.org/10.1207/S15327043HUP1701_5

Crant, J. (1996). The proactive personality scale as a predictor of entrepreneurial intention. Journal of Small Business Management, 34(3). https://homepages.se.edu/cvonbergen/files/2013/01/Proactive_Personality-Scale-as-aPredictor-of-Entrepreneurial-Intentions.pdf

Dalimunte, M. A. (2015). Meng-akselerasi pertumbuhan koperasi melalui pelibatan teknologi informatika. INFORMATIKA, 3(3), 1-8. https://doi.org/10.36987/informatika.v3i3.218

Engle, R., Dimitriadi, N., Gavidia, J., Schlaegel, C., Delanoë-Gueguen, S., Alvarado, I., He, X., Baume, S., \& Wolff, B. (2010). Entrepreneurial intent: A twelve country evaluation of Ajzen's model on planned behavior. International Journal of Entrepreneurial Behaviour and Research, 16, 35-57. https://doi.org/10.1108/13552551011020063

Gadar, K., \& Kamal, N. (2009). The influence of personality and socio-economic factors on female entrepreneurship motivations in Malaysia. International Review of Business Research Papers, https://citeseerx.ist.psu.edu/viewdoc/download?doi=10.1.1.512.7959\&rep=rep1\&type=pdf 
Gird, A., \& Bagraim, J. J. (2008). The theory of planned behaviour as predictor of entrepreneurial intent amongst final-year university students. South African Journal of Psychology, 38(4), 711-724. https://doi.org/10.10520/EJC98508

Gnyawali, D. R., \& Fogel, D. S. (1994). Environments for entrepreneurship development: Key dimensions and research implications. Entrepreneurship Theory and Practice, 18(4), 43-62. https://doi.org/10.1177/104225879401800403

Hadi, S. (2001). Analisis regresi (1st ed.). Andi.

Hamilton, B. H., Papageorge, N. W., \& Pande, N. (2018). The right stuff? personality and entrepreneurship. National Bureau of Economic Research Working Paper Series, No. 25006. https://doi.org/10.3386/w25006

Klyver, K., Hindle, K., \& Meyer, D. (2008). Influence of social network structure on entrepreneurship participation-A study of 20 national cultures. International Entrepreneurship and Management Journal, 4(3), 331-347. https://doi.org/10.1007/s11365007-0053-0

Menteri Pendidikan Nasional Republik Indonesia. (2008). Peraturan Menteri Pendidikan Nasional Republik Indonesia Nomor 39 Tahun 2008 tentang Pembinaan Kesiswaan.

Meredith, G. G., Neck, P. A., \& Nelson, R. E. (2000). Kewirausahaan teori dan praktek (D. Suseno (Ed.)). Pustaka Binaman Pressindo.

Nurbudiyani, I. (2013). Pengembangan model kewirausahaan SMK melalui koperasi sekolah. Anterior Jurnal, 12(2), 46-53. https://doi.org/10.33084/anterior.v12i2.306

Pemerintah Kabupaten Kulon Progo. (2012). SMKN 1 Nanggulan terima ISO 9001:2008. Kulonprogokab.Go.Id. https://kulonprogokab.go.id/v31/detil/2203/smkn-1-nanggulanterima-iso-90012008

Presiden Republik Indonesia. (2005). Peraturan Pemerintah Republik Indonesia Nomor 19 Tahun 2005 tentang Standar Nasional Pendidikan.

Puspitawati, H. (2009). Kenakalan pelajar (Dipengaruhi oleh sistem sekolah dan keluarga). IPB PRESS.

Salimath, M. S., \& Cullen, J. B. (2010). Formal and informal institutional effects on entrepreneurship: a synthesis of nation-level research. International Journal of Organizational Analysis, 18(3), 358-385. https://doi.org/10.1108/19348831011062175

Sari, D. P. (2013). Efektivitas peran koperasi sekolah sebagai unit pembelajaran kewirausahaan di SMP Negeri 1 Karanganyar Kabupaten Pekalongan. Economic Education Analysis Journal, 2(1), 14-17. https://journal.unnes.ac.id/sju/index.php/eeaj/article/view/1434/1528

Schmitt-Rodermund, E. (2004). Pathways to successful entrepreneurship: Parenting, personality, early entrepreneurial competence, and interests. Journal of Vocational Behavior, 65(3), 498518. https://doi.org/https://doi.org/10.1016/j.jvb.2003.10.007

Segal, G., Borgia, D., \& Schoenfeld, J. (2005). The motivation to become an entrepreneur. International Journal of Entrepreneurial Behavior \& Research, 11(1), 42-57. https://doi.org/10.1108/13552550510580834

Shane, S., Locke, E. A., \& Collins, C. J. (2003). Entrepreneurial motivation. Human Resource Management Review, 13(2), 257-279. https://doi.org/10.1016/S1053-4822(03)00017-2

Sommer, L. (2011). The theory of planned behaviour and the impact of past behaviour. International Business \& Economics Research Journal (IBER), 10(1), 91-110. https://doi.org/10.19030/iber.v10i1.930 
Suharti, L., \& Sirine, H. (2011). Faktor-faktor yang berpengaruh terhadap niat kewirausahaan (entrepreneurial intention). Profit: Jurnal Penerapan Ilmu Manajemen Dan Kewirausahaan, 13(2), 124-134. https://doi.org/10.9744/jmk.13.2.124-134

Suryana, S. (2008). Kewirausahaan: Pedoman praktis kiat dan proses menuju sukses. Salemba Empat.

ToMiRa, model pemberdayaan UMKM dari Kulon Progo. (2017). Nusakini.Com. https://nusakini.com/news/tomira-model-pemberdayaan-umkm-dari-kulon-progo

Warmanto, F., \& Thenu, H. (2009). Analisis hubungan antara sikap, norma subyektif, dan kontrol keperilakuan yang dirasakan terhadap perilaku berbagi pengetahuan manajer: Studi empiris pada perusahaan di wilayah Jakarta. Ultima Management : Jurnal Ilmu Manajemen, 1(1 SEArticles). https://ejournals.umn.ac.id/index.php/manajemen/article/view/164

Zhao, H., \& Seibert, S. (2006). The big five personality dimensions and entrepreneurial status: A meta-analytical review. The Journal of Applied Psychology, 91, 259-271. https://doi.org/10.1037/0021-9010.91.2.259 